\title{
Kandungan Nitrat Dan Fosfat Di Pantai Jungwok, Kabupaten Gunungkidul, Yogyakarta
}

\section{Nitrat and Phosphate Contents in Water Surface of Jungwok Beach, Gunungkidul District, Yogyakarta}

\author{
Heny Budi Setyorini ${ }^{1}$ dan Ernastin Maria $^{2}$ \\ ${ }^{1}$ Program Studi Teknik Kelautan, Fakultas Teknologi Sumber Daya Alam, Institut Teknologi Yogyakarta \\ ${ }^{2}$ Program Studi Teknik Industri, Fakultas Teknologi Industri, Institut Teknologi Yogyakarta
}

Email korespondensi: henybudis@ity.ac.id

\begin{abstract}
Evaluation of nitrate and phosphate content in seawater of Jungwok Beach, Gunungkidul District, Yogyakarta, was the aim of this study. The method used was a survey with a quantitative approach. Sampling in the eastern, central and western regions of Jungwok Beach was carried out using a purposive sampling technique using line transects. Nitrate and phosphate content analysis was conducted at the Laboratory of the Center for Environmental Health and Disease Control Engineering (BBTKLPP) Yogyakarta. The results showed that the nitrate concentration in Jungwok Beach ranged from 2.85 to $8.82 \mathrm{mg} / 1$, while the phosphate ranged from 0.00 to $0.50 \mathrm{mg} / 1$. Based on these results, the waters of Jungwok Beach are classified as mesotrophic to eutrophic waters. Overall the results of nitrate and phosphate have exceeded sea water quality standards for marine biota in the Decree of the Minister of Environment No. 51 of 2004 amounting to $0.008 \mathrm{mg} / 1$ and $0.015 \mathrm{mg} / 1$. In situ measurement results showed that temperature, $\mathrm{pH}$, DO and salinity at Jungwok Beach were respectively around $30.67 \pm 0.93-32.20+0.62^{\circ} \mathrm{C} ; 9.14 \pm 0.29-9.29 \pm 0.13 ; 8.00 \pm 1.41-8.93 \pm$ $1.19 \mathrm{mg} / 1$ and $34.83 \pm 0.46-35.10 \pm 0.10 \mathrm{ppt}$.
\end{abstract}

Keywords: Nitrat, Phosphate, Jungwok Beach, Gunungkidul

\section{PENDAHULUAN}

Pantai Jungwok merupakan salah satudestinasi pariwisata di Kabupaten Gunungkidul dan habitat bagi berbagai jenis biota laut termasuk makroalga. Hal ini didukung dengan jenis substrat Pantai Jungwok berupa karang mati dan pasir, masih minimnya aktivitas pariwisata dan tidak adanya muara sungai disekitar pantai tersebut, sehingga kealamiahan dan kualitas air Pantai Jungwok masih terjaga hingga kini.

Kualitas lingkungan perairan Pantai Jungwok terutama kandungan nitrat dan fosfat memegang peranan penting dalam mendukung kelangsungan hidup berbagai jenis biota laut. Sebagaimana dengan penjelasan Mustofa (2015), bahwa nitrat dan fosfat tergolong makronutrien yang dibutuhkan makhluk hidup dalam jumlah banyak.

Nitrat merupakan bentuk nitrogen utama di lingkungan perairan alami yang berasal dari ammonium dan masuk ke dalam badan sungai melalui limbah domestik (Mustofa, 2015). Berbeda dengan fosfat $\left(\mathrm{PO}_{4}\right)$ merupakan salah satu jenis nutrien yang tidak bisa dihilangkan keberadaannya di atmosfer, tetapi secara umum dapat dihilangkan dari lingkungan perairan melalui proses kimia atau biologi oleh fitoplankton di dalam sedimen (Da Silva, 2013). Selanjutnya menurut Patricia, Astono, \& Hendrawan (2018), keberadaan fosfat di lingkungan perairan bersumber dari limpasan pupuk pertanian, kotoran hewan atau manusia, sabun, pengolahan sayur, dan industri pulp dan kertas.

Besaran kandungan nitrat dan fosfat dalam lingkungan perairan juga sering dijadikan indikator kesuburan maupun pencemaran lingkungan perairan pantai. Menurut Effendi (2003); Mustofa (2015), klasifikasi tingkat kesuburan perairan berdasarkan kandungan nitrat antara lain: perairan oligotrofik (0-1 mg/l), mesotrofik (1-5 mg/l) dan eutrofik (5$50 \mathrm{mg} / \mathrm{l})$, sedangkan bila berdasarkan kandungan orthofosfat, antara lain: perairan oligotrofik $(0,003-0,010 \mathrm{mg} / \mathrm{l})$, mesotrofik (0,010-0,030 mg/l) dan eutrofik (0,03-0,1 mg/l).

Hasil penelitian Mustofa (2015), menunjukkan bahwa kandungan nitrat dan fosfat di Pantai Desa Tanggultlare Kecamatan Kedung Kabupaten Jepara dan BBPBAP (Balai Besar Pengembangan Budidaya Air Payau) Jepara masingmasing sekitar 0,882-1,711 mg/l dan 0,086-0,097 mg/l. Selanjutnya hasil penelitian Pramesti et al. (2016), juga menunjukkan bahwa kandungan nitrat dan fosfat di Pantai Krakal masing-masing sekitar 0,0683-0,5605 mg/l dan 0,0228-0,1770 mg/l. Begitu pula dengan hasil penelitian Herlinawati, Arthana, \& Dewi (2018), bahwa kandungan nitrat dan fosfat di perairan Pulau Serangan masing-masing sekitar 0,92 mg/l dan 0,86 mg/l.Hasil nitrat dan fosfat tersebut telah melampaui baku mutu air laut untuk biota laut pada Keputusan Menteri Negara Lingkungan Hidup Nomor 51 Tahun 2004 sebesar 0,008 mg/l dan 0,015 mg/l.

Tingginya kandungan nitrat dan fosfat dalam lingkungan perairan juga dapat memicu terjadinya pengkayaan unsur hara (eutrofikasi) yang selanjutnya dapat mengganggu kelangsungan hidup berbagai jenis biota laut. Proses eutrofikasi umumnya ditandai dengan blooming fitoplankton ataupun alga yang diikuti dengan penurunan kandungan oksigen terlarut dan kematian massal biota laut. 
Berdasarkan uraian tersebut, maka diperlukan kajian tentang kandungan nitrat dan fosfat di Pantai Jungwok, Kabupaten Gunungkidul bertujuan untuk mengetahui indikator kesuburan perairan.

\section{METODE PENELITIAN}

Penelitian ini dilaksanakan di Pantai Jungwok,Desa Jepitu, Kecamatan Girisubo, Kabupaten Gunungkidul, Yogyakarta pada bulan Mei 2019 saat air laut surut. Analisis kandungan nitrat dan fosfat dilakukan di Laboratorium Balai Besar Teknik Kesehatan Lingkungan dan Pengendalian Penyakit (BBTKLPP) Yogyakarta. Variabel penelitian ini meliputi kandungan nitrat dan fosfat air laut sebagai variabel bebas. Selain itu, variabel penelitian ini juga meliputi kualitas lingkungan perairan terutama suhu, oksigen terlarut, $\mathrm{pH}$ dan salinitas sebagai data pendukung.

Metode yang digunakan dalam penelitian ini adalah survei dengan pendekatan kuantitatif. Teknik pengambilan sampel air laut menggunakan purposive sampling. Lokasi pengambilan sampel air laut berada di bagian timur, tengah dan barat Pantai JungwokLokasi pengambilan sampel air laut berada di bagian timur, tengah dan barat Pantai Jungwok menggunakan transek garis. Pada masing-masing lokasi terdapat 3 titik sampling dengan jarak 0 meter, 5 meter dan 10 meter dari garis pantai. Pengambilan sampel air untuk pengukuran kandungan nitrat dan fosfat menggunakan botol polyetilen sebanyak 1 liter tiap titik, selanjutnya dimasukkan ke dalam cool box, untuk dianalisis di laboratorium. Pengukuran suhu, DO, $\mathrm{pH}$ dan salinitas dilakukan secara in situ menggunakan alat water quality monitor meter AZ8603. Analisis data kandungan nitrat dan fosfat menggunakan uji korelasi dengan MicrosoftExcel untuk mengetahui hubungan antara jarak titik sampling dengan kandungan nitrat dan fosfat.

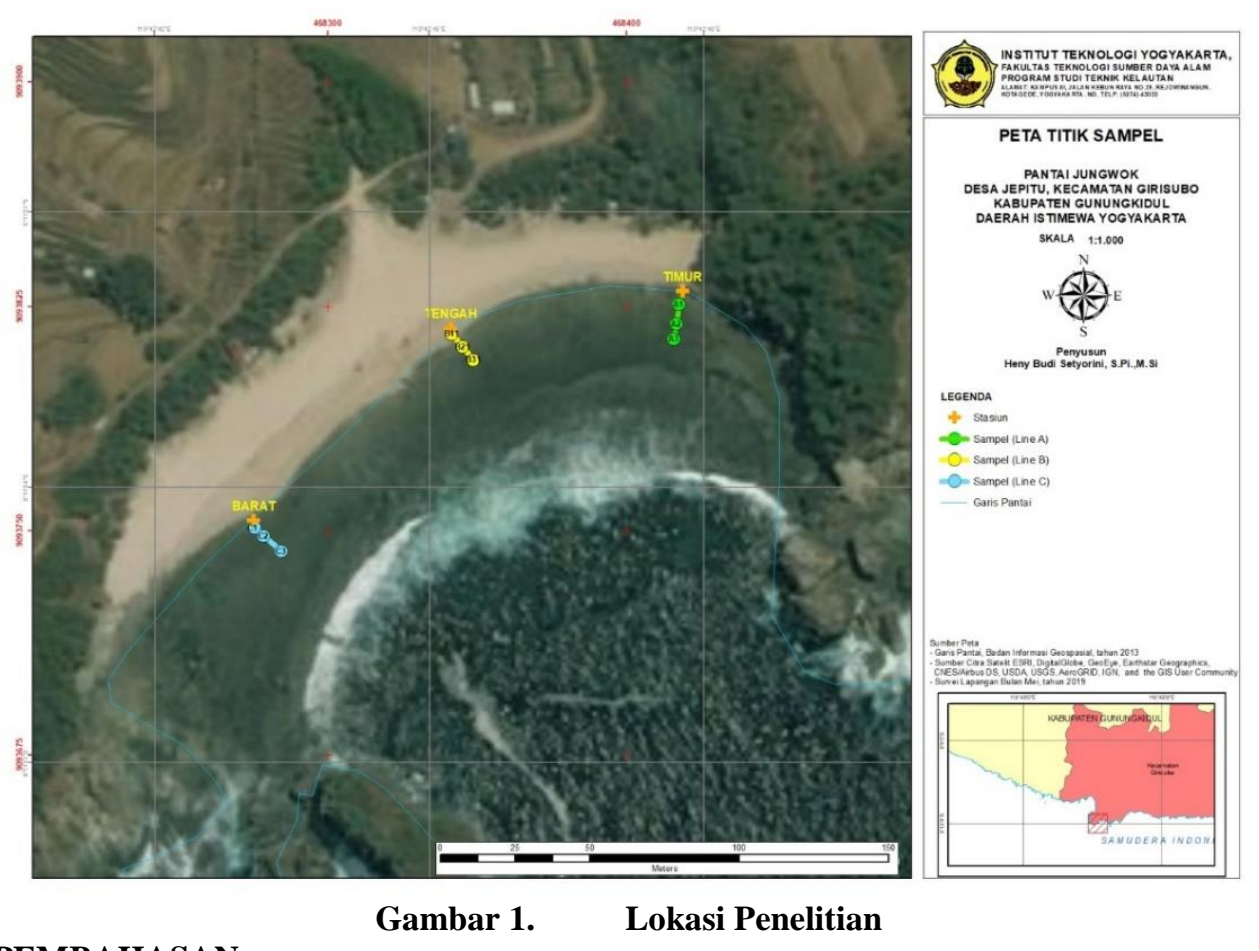

HASIL DAN PEMBAHASAN

Gambar 1. Lokasi Penelitian

Hasil

Hasil pengukuran nitrat dan fosfat tercantum pada Tabel 1. Grafik korelasi kandungan nitrat dan fosfat tercantum pada Gambar 2dan Gambar 3. Berdasarkan tabel tersebut dapat diketahui bahwa kandungan nitrat di bagian timur, tengah dan barat Pantai Jungwok masing-masing berkisar 3,38-4,15 mg/l, 4,24-8,82 mg/l dan 2,85-8,46 mg/l. Selanjutnya untuk kandungan fosfat di bagian timur, tengah dan barat Pantai Jungwok masing-masing berkisar 0,02$0,11 \mathrm{mg} / \mathrm{l}, 0,02-0,19 \mathrm{mg} / \mathrm{l}$ dan $0,00-0,50 \mathrm{mg} / \mathrm{l}$.

Berdasarkan grafik tersebut, diketahui bahwa nilai $\mathrm{R}^{2}$ pada kandungan nitrat Pantai Jungwok sebesar 0,3778, menunjukkan bahwa $37,78 \%$ kandungan nitrat tersebut dipengaruhi oleh perbedaan kedalaman perairan, sedangkan $62,22 \%$ dipengaruhi oleh faktor-faktor lainnya. Berbeda dengan nilai $\mathrm{R}^{2}$ pada kandungan fosfat Pantai Jungwok sebesar 0,5012, menunjukkan bahwa 50,12\% perbedaan kedalaman perairan, sedangkan 49,88\% dipengaruhi oleh faktor-faktor lainnya.

Hasil pengukuran secara in situ menunjukkan bahwa suhu, pH, DO dan salinitas di Pantai Jungwok masingmasing berkisar30,67 $\pm 0,93-32,20 \pm 0,62^{\circ} \mathrm{C} ; 9,14 \pm 0,29-9,29 \pm 0,13 ; 8,00 \pm 1,41-8,93 \pm 1,19 \mathrm{mg} / 1$ dan $34,83 \pm 0,46-35,10 \pm 0,10$ ppt. Selanjutnya tercantum pada Tabel 2. 
Tabel 1. Hasil Analisis Kandungan Nitrat dan Fosfat Pantai Jungwok

\begin{tabular}{cccc}
\hline No. & Lokasi & Nitrat $(\mathrm{mg} / \mathrm{l})$ & Fosfat $(\mathrm{mg} / \mathrm{l})$ \\
\hline 1. & A1 & 3.92 & 0.07 \\
2. & A2 & 4.15 & 0.02 \\
3. & A3 & 3.38 & 0.11 \\
\hline & Rerata & 3.82 & 0.07 \\
\hline & SD & 0.40 & 0.05 \\
\hline 4. & & & 0.19 \\
5. & B1 & 4.24 & 0.02 \\
6. & B2 & 8.82 & 0.10 \\
\hline & B3 & 8.70 & 0.10 \\
& Rerata & 7.25 & 0.09 \\
\hline 7. & SD & 2.61 & 0.24 \\
9. & C1 & 2.85 & 0.00 \\
\hline & C2 & 3.48 & 0.50 \\
\hline C3 & 8.46 & 0.25 \\
\hline
\end{tabular}

\section{Keterangan:}
A : Timur
B : Tengah
C : Barat

Kandungan Nitrat Pantai Jungwok

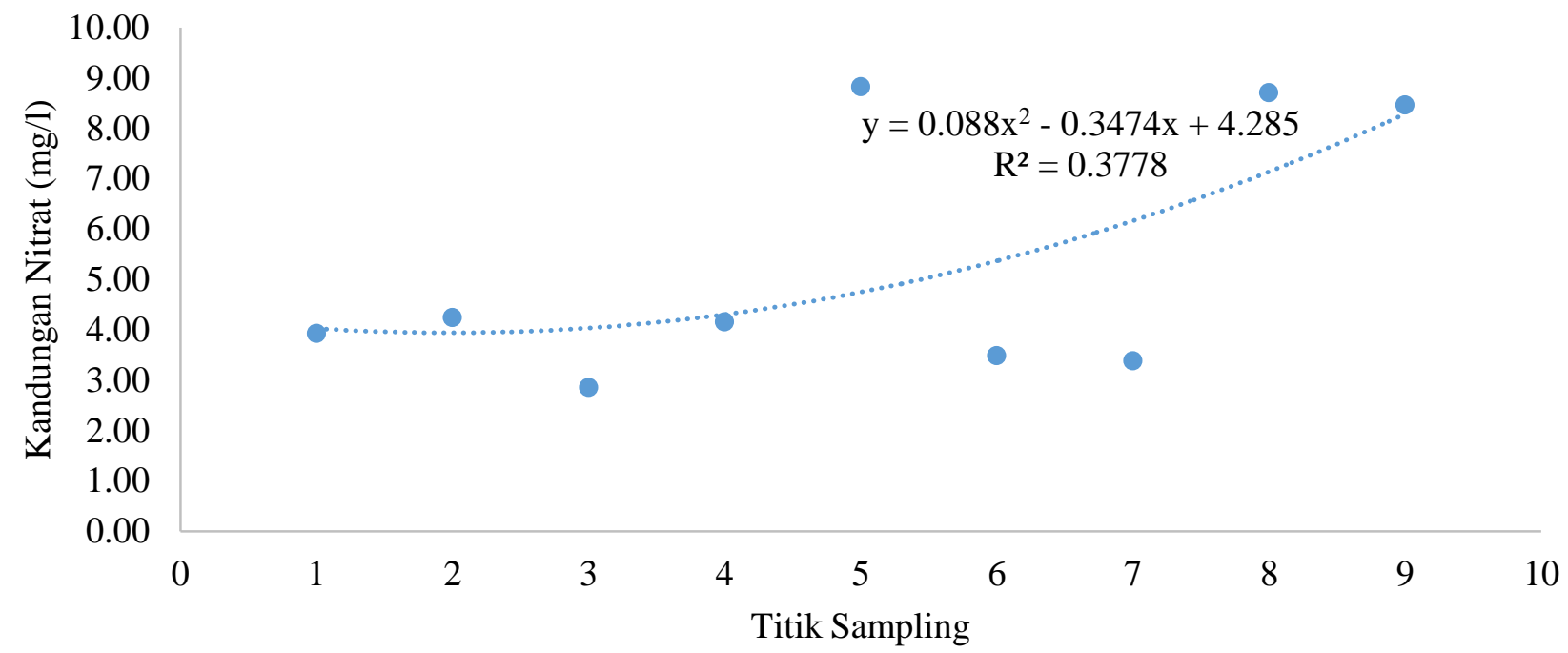

Gambar 2. Kandungan Nitrat Pantai Jungwok 


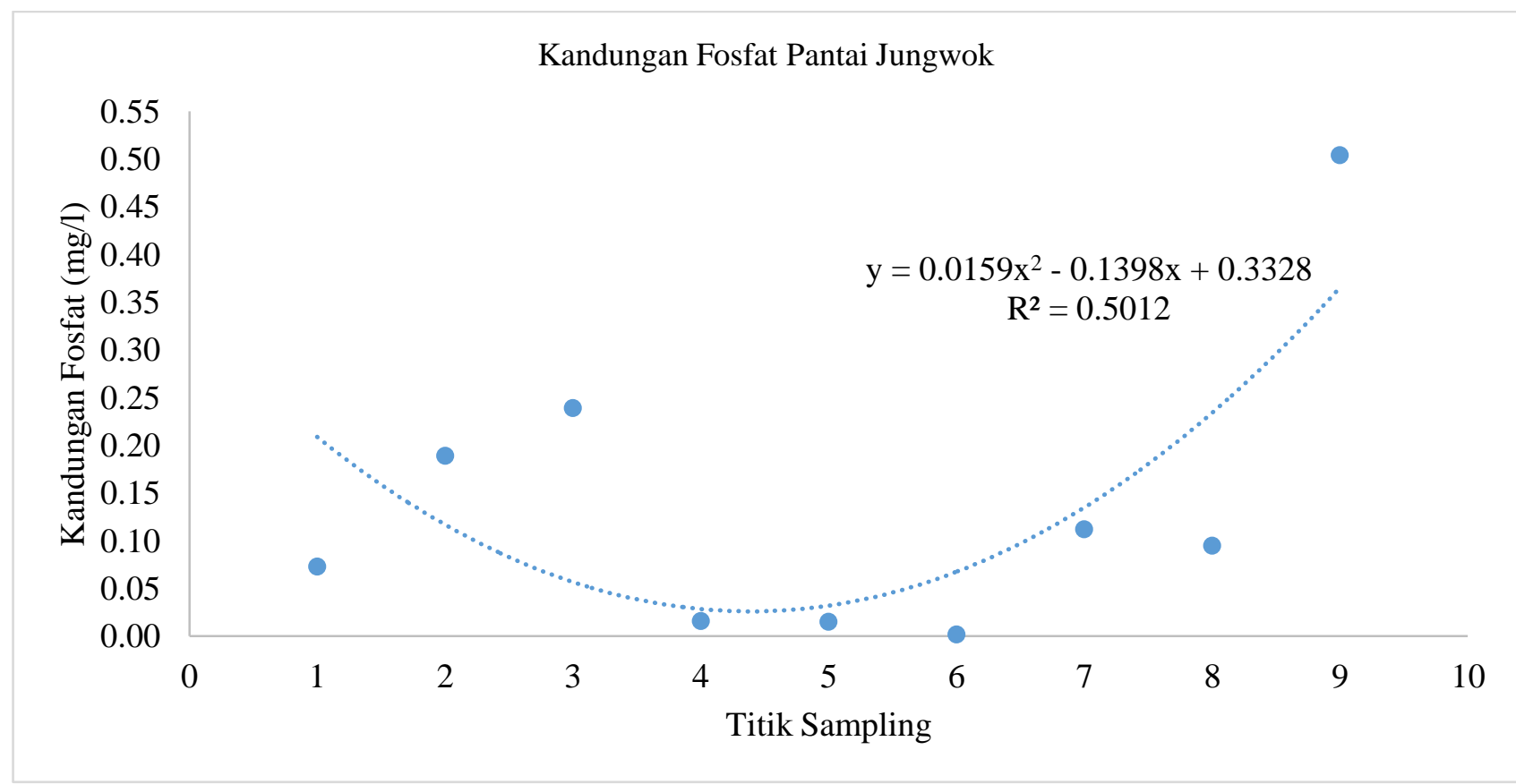

Gambar 3. Kandungan Fosfat Pantai Jungwok

Tabel 2. Hasil Pengukuran Kualitas Air

\begin{tabular}{clcccc}
\hline No. & Lokasi & Suhu $\left({ }^{\circ} \mathrm{C}\right)$ & $\mathrm{pH}$ & $\mathrm{DO}(\mathrm{mg} / \mathrm{l})$ & Salinitas $(\mathrm{ppt})$ \\
\hline 1. & $\mathrm{~A} 1$ & 32,00 & 9,17 & 5,70 & 35,10 \\
2. & $\mathrm{~A} 2$ & 32,90 & 9,37 & 10,70 & 35,20 \\
3. & $\mathrm{~A} 3$ & 31,70 & 9,26 & 9,80 & 35,00 \\
\hline & Rerata & 32,20 & 9,27 & 8,73 & 35,10 \\
& SD & 0,62 & 0,10 & 2,67 & 0,10 \\
\hline 4. & B1 & 31,70 & 9,40 & 9,30 & 34,30 \\
5. & B2 & 30,40 & 9,20 & 8,20 & 35,10 \\
6. & B3 & 29,90 & 8,83 & 6,50 & 35,10 \\
\hline & Rerata & 30,67 & 9,14 & 8,00 & 34,83 \\
& SD & 0,93 & 0,29 & 1,41 & 0,46 \\
\hline 7. & C1 & 32,10 & 9,38 & 8,40 & 34,40 \\
8. & C2 & 31,20 & 9,35 & 10,30 & 35,10 \\
9. & C3 & 30,20 & 9,14 & 8,10 & 35,10 \\
\hline & Rerata & 31,17 & 9,29 & 8,93 & 34,87 \\
& SD & 0,95 & 0,13 & 1,19 & 0,40 \\
\hline
\end{tabular}

\section{Pembahasan}

\section{Nitrat}

Berdasarkan kandungan nitrat pada bagian timur, maka perairan tersebut cenderung termasuk mesotrofik, sedangkan untuk bagian tengah cenderung eutrofik, dan barat cenderung mesotrofik dan eutrofik. Menurut Prihatin, Setyono, \& Sunarto (2018), perairan mesotrofik merupakan perairan dengan kandungan unsur hara dan nutrien dalam kategori sedang dan belum tercemar.Selanjutnyaperairaneutrofik merupakan perairan yang memiliki nutrien yang tinggi dan dapat mendukung kelangsungan hidup tumbuhan dan hewan di perairan tersebut (Febbrianna, Muskananfola, \& Suryanti, 2017).

Tingginya kandungan nitrat di Pantai Jungwok dipengaruhi oleh keberadaan berbagai jenis makroalga seperti Ulva sp., Gracillaria sp., Boergesenia sp., Euchema sp., dan Enteromorpha sp.Selanjutnya proses penguraian makroalga tersebut oleh dekomposer turut meningkatkan unsur hara. Sebagaimana penjelasan Mustofa (2015), bahwa keberadaan vegetasi mangrove dapat meningkatkan kesuburan perairan melalui penguraian serasah daun mangrove oleh 
dekomposer terutama bakteri dan jamur. Selain itu, proses penguraian dari sisa aktivitas beberapa jenis biota lautyang ditemukan di Pantai Jungwok seperti gastropoda, polychaeta dan moluska juga turut meningkatkan kandungan nitrat.

Jenis substrat Pantai Jungwok yang berupa karang mati dan pasir turut menunjang tingginya kandungan nitrat. Hal ini dikarenakan keberadaan mikrobentos pada tipe pantai berbatu cenderung sedikit dibandingkan dengan tipe pantai berlumpur sehingga penguraian mineral dan bahan-bahan organik kurang optimal. Risamasu \& Prayitno (2011), menjelaskan lebih lanjut bahwa sedimen turut mempengaruhi konsentrasi nitrat di bagian dasar perairan, sedangkan nitrat pada bagian lapisan permukaan cenderung dimanfaatkan oleh fitoplankton.

Perbedaan kedalaman perairan dan waktu pengambilan sampel juga turut mempengaruhi kandungan nitrat. Hasil penelitian Risamasu \& Prayitno, (2011), menunjukkan bahwa kandungan nitrat tertinggi di perairan Kepulauan Matasiri, Kalimantan Selatanterdapat pada kedalaman perairan 54 meter sekitar 0,048 mg/l, sedangkan terendah pada kedalaman 42 meter sekitar 0,024 mg/l pada bulan November 2010. Berbeda dengan lapisan permukaan, kandungan nitrat tertinggi justru terdapat pada kedalaman 32 meter sekitar 0,069 mg/l, sedangkan terendah pada kedalaman 56 meter sekitar 0,023 mg/l (Risamasu \& Prayitno, 2011). Kondisi tersebut, juga sesuai dengan penjelasanLestari (2014), bahwa pada perairan dangkal, kandungan nitrat juga dipengaruhi oleh turbulensi yang mampu mengangkat senyawa nitrat dari dasar kolom air.

Pengaruh perbedaan musim terhadap kandungan nitrat di perairan telah dibuktikan oleh hasil penelitian Faizal, Jompa, Nessa,\& Rani (2012), yang menunjukkan bahwa kisaran konsentrasi nitrat di perairan Kepulauan Spermonde pada musim hujan sekitar 18-418 $\mu \mathrm{g} / \mathrm{L}$, sedangkan pada musim kemarau sekitar 18-278 $\mu \mathrm{g} / \mathrm{L}$. Selanjutnyahasil penelitian Lestari (2014), juga menunjukkan bahwa kandungan nitrat di perairan pesisir Tanjungpinang pada September 2013 berkisar 0,038-0,296 mg/l.Hal ini sesuai dengan penjelasan Patricia et al. (2018), bahwa kandungan nitrat dalam lingkungan perairan berfluktuasi menurut musim, dimana kandungan nitrat yang lebih tinggi terjadi setelah hujan lebat.

Secara keseluruhan, hasil kandungan nitrat Pantai Jungwok juga telah melampaui baku mutu air laut untuk biota laut pada Keputusan Menteri Negara Lingkungan Hidup Nomor 51 Tahun 2004 sebesar 0,008 mg/l. Hasil kandungan nitrat yang tinggi tersebut dapat memicu eutrofikasi. Hal ini sesuai dengan penjelasan Lestari (2014), bahwa pembuangan beban nitrogen ke lingkungan perairan pesisir dapat menyebabkan terjadinya eutrofikasi sehingga mengganggu keseimbangan sistem dan berdampak buruk pada ekosistem. Selanjutnya menurut Davis dan Cornwell (1991) dalam Effendi (2003), apabila kandungan nitrat di lingkungan perairan lebih dari 0,2 mg/l, maka dapat mengakibatkan eutrofikasi dan menstimulir blooming fitoplankton dan alga serta mengganggu proses penetrasi cahaya matahari dan fotosintesis.Risamasu \& Prayitno (2011), menjelaskan lebih lanjut bahwa potensi blooming tersebut cenderung didominasi oleh jenis alga yang berbahaya atau Harmful Algae Blooms (HABs).

\section{Fosfat}

Berdasarkan kandungan fosfat pada bagian timur Pantai Jungwok, maka perairan tersebut cenderung termasuk oligotrofik, sedangkan untuk bagian tengah dan barat cenderung mesotrofik dan eutrofik. Perairan oligotrofik dicirikan dengan perairan yang jernih, dalam dan memiliki kelimpahan tumbuhan laut seperti alga (Febbrianna et al., 2017).

Biota laut memerlukan fosfat sebagai nutrien untuk melangsungkan kehidupannya, akan tetapi kandungan fosfat yang tinggi dalam lingkungan perairan dapat menimbulkan pertumbuhan alga dalam jumlah yang sangat besar dan menghambat penetrasi cahaya matahari (Patricia et al., 2018). Secara keseluruhan, hasil pengukuran fosfat pada penelitian ini yang berkisar $0,00-0,50 \mathrm{mg} / \mathrm{l}$ juga dapat mendukung kelangsungan hidup makroalga. Sebagaimana penjelasan Herlinawati et al. (2018), bahwa kandungan nitrat sebesar 0,86 mg/l di perairan Pulau Serangan diduga dapat mendukung kelangsungan pertumbuhan makroalga secara alami dan optimal.

Tingginya kandungan fosfat di Pantai Jungwok terkait adanya proses difusi dari sedimen. Sebagaimana penjelasan Risamasu \& Prayitno (2011), bahwa sedimen merupakan tempat penyimpanan utama fosfor di lautan, terutama dalam bentuk partikulat yang berikatan dengan oksida besi dan senyawa hidroksida. Selanjutnya menurutOnwugbuta-Enyi, Zabbey, \& Erondu (2008), bahwa perbedaan kandungan fosfat juga disebabkan oleh perilaku unik fosfor di dalam lingkungan perairan dangkal, dimana fosfor akan cepat terserap di bagian permukaan lumpur kemudian akan masuk kembali ke kolom air melalui proses yang tidak diketahui.

Serupa dengan nitrat, perbedaan kedalaman dan waktu pengambilan sampel turut mempengaruhi kandungan fosfat. Hasil penelitian Risamasu \& Prayitno (2011), telahmenunjukkan bahwa kandungan fosfat tertinggi di perairan Kepulauan Matasiri, Kalimantan Selatanterdapat pada kedalaman perairan 56 meter sekitar 0,016 mg/l, sedangkan terendah pada kedalaman 47 dan 51 meter sekitar 0,001 mg/l pada bulan November 2010. Berbeda dengan lapisan permukaan, kandungan fosfat tertinggi justru terdapat pada kedalaman 44 meter sekitar 0,016 mg/l, sedangkan terendah pada kedalaman 47 dan 51 meter sekitar 0,001 mg/l (Risamasu \& Prayitno, 2011).

Pengaruh perbedaan musim terhadap kandungan fosfat di perairan telah ditunjukkan oleh hasil penelitian Faizal et al. (2012), bahwa kandungan fosfat di perairan Kepulauan Spermonde pada musim hujan sekitar 19-71 $\mu \mathrm{g} / \mathrm{L}$, sedangkan pada musim kemarau sekitar 19-91 $\mu \mathrm{g} / \mathrm{L}$. Selain itu, pasang surut air laut juga turut mempengaruhi kandungan fosfat. Hasil penelitian Karil, Yusuf, \& Maslukah (2015), menunjukkanbahwa transpor fosfat di perairan Teluk Ujungbatu terjadi saat surut melalui muara sungai yang menjadi tempat keluaran berbagai aktivitas masyarakat yang berpotensi menghasilkan limbah fosfat seperti detergen. Selanjutnya Prihatin et al. (2018), juga menjelaskan bahwa kandungan fosfat tertinggidi Mangrove Tapak Tugurejo Semarang berada di lokasi yang berdekatan dengan daratan dan terlindung dari pasang surut, sebaliknya kandungan fosfat terendah berada di lokasi yang berdekatan dengan perairan pantai dan dibatasi oleh pasang surut. 
Secara keseluruhan, hasil kandungan fosfat Pantai Jungwok juga telah melampaui baku mutu air laut untuk biota laut pada Keputusan Menteri Negara Lingkungan Hidup Nomor 51 Tahun 2004 sebesar 0,015 mg/l. Hasil kandungan fosfat yang tinggi tersebut juga dapat memicu eutrofikasi seperti halnya dengan nitrat.

\section{Kualitas Air}

Parameter kualitas air seperti suhu, pH, oksigen terlarut dan salinitas juga dapat mempengaruhi kandungan nitrat dan fosfat di lingkungan perairan Pantai Jungwok. Hasil penelitian Karil et al. (2015), menunjukkan bahwa arus laut dan parameter fisika kimia perairan seperti suhu, kedalaman, salinitas, $\mathrm{pH}$ dan kandungan oksigen terlarut diduga telah mempengaruhi nilai konsentrasi nitrat dan fosfat. Selanjutnya Utami, Maslukah, \& Yusuf (2016), menjelaskan bahwa tingginya nilai salinitas di dalam lingkungan perairan dapat mempengaruhi kandungan nitrat pada perairan tersebut.

Hasil penelitian ini juga serupa dengan hasil penelitian Utami et al. (2016), yang menunjukkan bahwa nilai suhu, $\mathrm{pH}$, oksigen terlarut dan salinitas di perairan Karangsong Kabupaten Indramayu masing-masing berkisar 26-29, $8^{0} \mathrm{C}$; 6,41-8,07; 2,29-5,3 mg/l dan 33-35\%. Hasil penelitian Gaol, Diansyah, \& Purwiyanto (2017), juga menunjukkan bahwa nilai suhu, kedalaman $\mathrm{pH}$, oksigen terlarut dan salinitas di perairan Selat Bangka Bagian Selatan masing-masing berkisar 28,5-30,8 ${ }^{\circ} \mathrm{C}$; 33,2 meter; 6,11-8,29; 5,75- 7,29 ppm; dan 29,54-31,46 psu.

Secara keseluruhan, berdasarkan Keputusan Menteri Negara Lingkungan Hidup Nomor 51 Tahun 2004 tentang baku mutu air laut, maka hasil pengukuran suhu, $\mathrm{pH}$, oksigen terlarut dan salinitas pada penelitian ini masih dapat mendukung kelangsungan hidup biota laut di Pantai Jungwok.

\section{KESIMPULAN}

Kandungan nitrat di Pantai Jungwok berkisar 2,85-8,82 mg/l, sedangkan fosfat berkisar 0,00-0,50 mg/l. Berdasarkan hasil kandungan nitrat dan fosfat tersebut, maka perairan Pantai Jungwok tergolong dalam perairan mesotrofik hingga eutrofik. Secara keseluruhan hasil nitrat dan fosfat tersebut telah melampaui baku mutu air laut untuk biota laut pada Keputusan Menteri Negara Lingkungan Hidup Nomor 51 Tahun 2004 sebesar 0,008 mg/l dan 0,015 $\mathrm{mg} / \mathrm{l}$. Hasil pengukuran secara in situ menunjukkan bahwa suhu, pH, DO dan salinitas di Pantai Jungwok masingmasing berkisar $30,67 \pm 0,93-32,20 \pm 0,62^{\circ} \mathrm{C} ; \quad 9,14 \pm 0,29-9,29 \pm 0,13 ; 8,00 \pm 1,41-8,93 \pm 1,19 \mathrm{mg} / 1$ dan $34,83 \pm 0,46-$ $35,10 \pm 0,10$ ppt. Hasil tersebut masih dapat mendukung kelangsungan hidup berbagai jenis biota laut di Pantai Jungwok.

\section{UCAPAN TERIMA KASIH}

Penulis mengucapkan terima kasih kepada Kementerian Riset, Teknologi, dan Pendidikan Tinggi Republik Indonesia yang telah memberikan bantuan dana penelitian dalam skema Hibah Penelitian Dosen Pemula Tahun Anggaran 2019. Yayasan Lingkungan Hidup dan seluruh civitas akademik Institut Teknologi Yogyakarta atasdukungan terhadap penelitian ini, Dinas Penanaman Modal dan Pelayanan Terpadu Kabupaten Gunungkidul, dan Dinas Kelautan dan Perikanan Kabupaten Gunungkidul atas pemberian izin penelitian, serta seluruh pihak yang telah membantu pelaksanaan penelitian ini.

\section{DAFTAR PUSTAKA}

Da Silva, K. R. (2013). Nitrogen and Phosphorus Dynamics in the Biofloc Production of the Pacific White Shrimp, Litopenaeus vannamei. Journal of the World Aquaculture Society, 44(1), 30-41.

Effendi, H. (2003). Telaah Kualitas Air bagi Pengelolaan Sumber Daya dan Lingkungan Perairan. Yogyakarta: Kanisius.

Faizal, A., Jompa, J., Nessa, N., \& Rani, C. (2012). Dinamika Spasio-Temporal Tingkat Kesuburan Perairan di Kepulauan Spermonde, Sulawesi Selatan. Seminar Nasional Tahunan IX Hasil Penelitian Perikanan Dan Kelautan-Semnaskan UGM, 1-18. Yogyakarta: UGM.

Febbrianna, V., Muskananfola, M. R., \& Suryanti. (2017). Produktivitas Primer Perairan Berdasarkan Kandungan Klorofil-a dan Kelimpahan Fitoplankton di Muara Sungai Bedono Demak. Journal of Maquares, 6(3), 318-324.

Gaol, A. S. L., Diansyah, G., \& Purwiyanto, A. I. S. (2017). Analisis Kualitas Air Laut di Perairan Selat Bangka Bagian Selatan. Maspari Journal, 9(1), 9-16.

Herlinawati, N. D. P. D., Arthana, I. W., \& Dewi, A. P. W. K. (2018). Keanekaragaman dan Kerapatan Rumput Laut Alami Perairan Pulau Serangan Denpasar Bali. Journal of Marine and Aquatic Sciences, 4(1), 22-30.

Karil, A. R. F., Yusuf, M., \& Maslukah, L. (2015). Studi Sebaran Konsentrasi Nitrat dan Fosfat di Perairan Teluk Ujungbatu Jepara. Jurnal Oseanografi, 4(2), 386-392. 
Lestari, F. (2014). Sebaran Nitrogen Anorganik Terlarut di Perairan Pesisir Kota Tanjungpinang, Kepulauan Riau. Dinamika Maritim, IV(2), 88-96.

Mustofa, A. (2015). Kandungan Nitrat dan Pospat Sebagai Faktor Tingkat Kesuburan Perairan Pantai. Jurnal Disprotek, $6(1), 13-19$.

Onwugbuta-Enyi, J., Zabbey, N., \& Erondu, E. S. (2008). Water Quality of Bodo Creek in the Lower Niger Delta Basin. Advances in Environmental Biology, 2(3), 132-136.

Patricia, C., Astono, W., \& Hendrawan, D. I. (2018). Kandungan Nitrat dan Fosfat di Sungai Ciliwung. Seminar Nasional Cendikiawan Ke 4, 179-185.

Pramesti, R., Susanto, A. B., Wilis, A. S., Ridlo, A., Subagiyo, \& Oktaviaris, Y. (2016). Struktur Komunitas dan Anatomi Rumput Laut di Perairan Teluk. Jurnal Kelautan Tropis, 19(2), 81-94.

Prihatin, A., Setyono, P., \& Sunarto. (2018). Sebaran Klorofil-a, Nitrat, Fosfat dan Plankton Sebagai Indikator Kesuburan Ekosistem di Mangrove Tapak Tugurejo Semarang. Jurnal Ilmu Lingkungan, 16(1), 68-77. https://doi.org/10.14710/jil.16.1.68-77

Risamasu, F. J. L., \& Prayitno, H. B. (2011). Kajian Zat Hara Fosfat, Nitrit, Nitrat dan Silikat di Perairan Kepulauan Matasiri, Kalimantan Selatan. Ilmu Kelautan, 16(3), 135-142.

Utami, T. M. R., Maslukah, L., \& Yusuf, M. (2016). Sebaran Nitrat (NO3) dan Fosfat (PO4) di Perairan Karangsong Kabupaten Indramayu. Buletin Oseanografi Marina, 5(1), 31-37. 